\title{
PERSEPSI MASYARAKAT KABUPATEN PURWAKARTA TERHADAP PENGOBATAN TRADISIONAL BERDASARKAN KELOMPOK USIA
}

\author{
*Reti Puji Handayani, Jenta Puspariki, Tiya Nurmala \\ Prodi Diploma Tiga Farmasi, Sekolah Tinggi Ilmu Kesehatan Purwakarta, Jl. Veteran \\ No.272 Ciseureuh Purwakarta. \\ *puji@ stikesholistic.ac.id \\ jenta@stikesholistic.ac.id \\ tiyanurmala63@gmail.com
}

\begin{abstract}
ABSTRAK
Guna mendukung upaya Pemerintah dalam mewujudkan derajat kesehatan optimal, masyarakat didorong untuk dapat memilih pengobatannya sendiri termasuk keputusan memilih pengobatan tradisional yang masih banyak digunakan sebagai alternatif memelihara dan mengatasi masalah kesehatan. Dalam hal ini, perilaku kesehatan tersebut dipengaruhi oleh faktor predisposisi, pemungkin dan faktor penguat. Penelitian bertujuan melihat faktor perilaku yang melatarbelakangi pemilihan pengobatan tradisional berdasarkan tiga kelompok usia di Kabupaten Purwakarta dengan menghubungksn pernyataan dari kuisioner yang diberikan dan mencari korelasi antar faktor tersebut. Penelitian dengan pendekatan kualitatif jenis eksplanatif asosiatif ini menggunakan subjek masyarakat Kabupaten Purwakarta sebanyak 137 orang melalui instrumen kuesioner yang diisi oleh kelompok masyarakat perkotaan, masyarakat urban dan masyarakat pedesaan. Persepsi masyarakat Kabupaten Purwakarta setuju terhadap tingkat pengetahuan dan animo pada pengobatan tradisional sebesar 57,7\%, dalam hal ini termasuk dalam faktor predisposisi. Sementara faktor penguat dilihat dari persepsi potensi pengembangan, masyarakat setuju pengobatan tradisional tumbuh menjamur, warisan nenek moyang dan biaya pelayanan tergolong murah sebesar 59,9\%. Masyarakat juga setuju pengobatan tradisional memberi bukti menyembuhkan penyakit sebesar 51,7\% (skala cukup). Variabel lain menunjukkan semua kelompok usia setuju fasilitas praktik dari upaya pengobatan tradisional masih seadanya (57,0\%), peneliti menganggapnya sebagai faktor pemungkin. Diperoleh bahwa perkembangan pengobatan tradisional diapresiasi oleh masyarakat dari semua kelompok usia. Dimana kelompok usia diatas 40 tahun, menyatakan persetujuan paling tinggi bahwa pengobatan tradisional potensial untuk dikembangkan, memiliki khasiat untuk penyembuhan namun fasilitas pengobatan belum terstandar dibandingkan kelompok usia 30-40 tahun maupun dibawah 30 tahun.
\end{abstract}

Kata kunci: Usia, Pengobatan tradisional, Persepsi 


\begin{abstract}
ABCTRAC
In order to support the Government's efforts in achieving optimal health status, people are encouraged to be able to choose their own treatment, including the decision to choose traditional medicine is still widely used as an alternative to maintaining and health problems. In this case, the health behavior is influenced by predisposing, enabling, and reinforcing factors. The study aims to look at behavioral factors behind the selection of traditional medicine is based on three age groups in Purwakarta with menghubungksn statements from a questionnaire and looking for correlations between these factors. The study with qualitative approach kind of explanatory associative, with subjects society Purwakarta 137 people through questionnaire filled out by a group of urban communities, urban communities and rural communities. The public perception Purwakarta agree on the level of knowledge and interest in the traditional medicine of $57.7 \%$, in this case, including the predisposing factors. While reinforcing factors seen from the perception of the potential development, community agrees traditional medicine flourished, ancestral and relatively cheap service charges amounted to 59.9\%. Traditional medical community agrees also gave evidence of cure of $51.7 \%$ (enough scale). The other variables showed all age groups agreed the practice facility of the traditional treatment efforts are still modest (57.0\%), the researchers think of it as an enabling factor. Provided that the development of traditional medicine to be appreciated by people of all age groups. Where the age group over 40 years, stating the highest approval that the potential for development of traditional medicine, has properties for healing but not yet standardized treatment facilities compared to those 30-40 years of age and under 30 years.
\end{abstract}

Keywords: Age, Traditional medicine, Perception 


\section{PENDAHULUAN}

Setiap warga Negara Indonesia mempunyai hak yang sama dalam mendapatkan derajat kesehatan yang optimal, hal ini sesuai dalam Undang-Undang Kesehatan Nomor 36 Tahun 2009. Guna mendukung upaya tersebut Pemerintah bertanggung jawab mengadakan dan mengatur pelayanan kesehatan dalam bentuk memelihara dan meningkatkan kesehatan, mencegah dan menyembuhkan penyakit serta memulihkan kesehatan perseorangan, keluarga, kelompok ataupun masyarakat (Depkes RI, 2009).

Studi perilaku pencarian pengobatan pada orang sakit menyangkut pada pertanyaan pokok, diantaranya sumber pengobatan apa yang dianggap mampu mengobati sakit. Sementara itu, diketahui bahwa sumber pengobatan dapat berasal dari pengobatan rumah tangga/pengobatan sendiri, pengobatan medis serta pengobatan tradisional (Supardi, Sudibyo dan Susyanti L, Andi. 2007).

Kesadaran masyarakat untuk beralih kepada pengobatan tradisional semakin meningkat dan masih banyak digunakan sebagai alternatif dalam upaya memelihara dan mengatasi masalah kesehatan (Ismiyana, Fariza.2013). Hal ini dibuktikan dengan penelitian di berbagai dunia yang menunjukkan bahwa pengobatan tradisional sudah sangat umum digunakan. Data WHO menyatakan $80 \%$ penduduk di negara berkembang dan $65 \%$ penduduk di negara maju memilih menggunakan obat tradisional karena dianggap usia harapan hidup menjadi lebih panjang untuk prevalensi penyakit kronis. Faktor lainnya dapat disebabkan adanya kegagalan penggunaan obat modern untuk penyakit seperti kanker serta meluasnya informasi obat tradisional yang diakses di seluruh dunia. Diperoleh bahwa angka penjualan global obat tradisional mendekati nilai 60 miliar dollar Amerika Serikat setiap tahunnya dari Data sekretariat Convention on Biological Diversity (CBD) (Utami, E.R.2018).

Pengobatan tradisional merupakan integrasi antara kebudayaan dan pengetahuan masyarakat. Pengalaman empiris nenek moyang yang menyatu dengan alam menumbuhkan kesadaran bahwa alam adalah penyedia obat bagi dirinya sendiri dan masyarakat (Jabbar, dkk.2016). Dalam hal ini, keputusan penggunaan pengobatan tradisional adalah suatu perilaku kesehatan yang dapat dilihat sebagai fungsi pengaruh kolektif dari faktor predisposisi (pengetahuan, sikap dan persepsi sakit); faktor pemungkin (seperti ketersediaan dan keterjangkauan terkait biaya) serta faktor penguat (dukungan lingkungan sosial) (Supardi, Sudibyo dan Susyanti L, Andi. 2007). Dalam hal 
ini faktor usia dapat saja berpengaruh dalam menentukan pemilihan pengobatan tradisional di Kabupaten Purwakarta yang juga memiliki program kesehatan dalam upaya peningkatan, pemusatan dan pembudidayaan dalam bidang tanaman obat yang sejalan dengan Pra Musrenbang BKPP Wilayah II Bappeda Provinsi Jawa Barat Tahun 2015. Penelitian Sudibyo Supardi, dalam data Susenus 2007 menunjukkan proporsi penggunaan obat tradisional pada responden kelompok usia lanjut lebih tinggi $(39,1 \%)$ daripada responden yang belum lanjut usia $(15,4 \%)$. Hal ini mungkin disebabkan karena orang tua lebih menyukai penggunaan obat tradisional karena lebih mudah dan praktis.

Berdasarkan latar belakang tersebut, maka peneliti ingin mengeksplorasi hubungan antara karakteristik kelompok usia responden terhadap persepsi masyarakat pada pengobatan trasidional di Kabupaten Purwakarta.

\section{METODE PENELITIAN}

Alur berpikir dalam penelitian ini diawali dengan adanya hubungan pengaruh tingkat persepsi dan animo masyarakat, potensi pengembangan, tingkat kepercayaan khasiat dan standarisasi pengobatan tradisional berdasarkan karakteristik kelompok usia di Kabupaten Purwakarta yang diperoleh dari pernyataan kuisioner yang meliputi pengobatan tradisional makin tumbuh menjamur (X1), pengobatan tradisional adalah warisan nenek moyang (X2), cara pengobatan tradisional cukup memberi bukti menyembuhkan penyakit (X3), fasilitas praktik pelayanan pengobatan tradisional seadanya (X4) serta pernyataan biaya pelayanan pelayanan pengobatan tradisional murah (X5) sehingga dibuat kerangka konsep penelitian sebagai berikut :

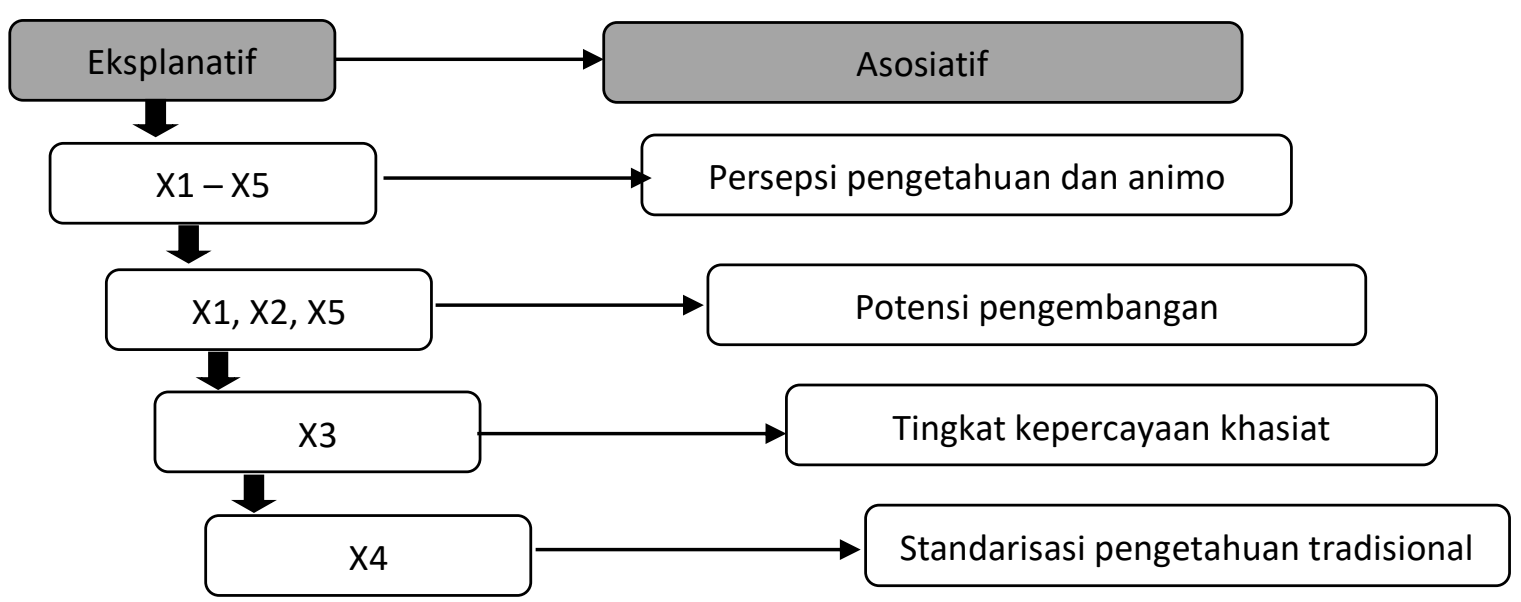

Gambar 1. Kerangka Konsep Penelitian 
Penelitian ini dilakukan dengan pendekatan kualitatif untuk mencari korelasi antara dua atau lebih variabel sehingga disebut dengan penelitian eksplanatif asosiatif (Sugiyono, 2017). Subjeknya adalah masyarakat Kabupaten Purwakarta sebanyak 137 orang dengan keragaman karakteristik yang dikelompokkan berdasarkan usia (dibawah 30 tahun; 3040 tahun dan 40 tahun keatas). Data penelitian diambil melalui instrumen kuesioner yang diisi oleh kelompok masyarakat perkotaan, masyarakat transisi (urban) dan masyarakat pedesaan dengan menghubungkan pernyataan (X1 - X5) dalam instrumen kuesioner dan kemudian diterjemahkan dalam korelasi faktor predisposisi, pemungkin atau faktor penguat penyebab perilaku masyarakat Kabupaten Purwakarta terhadap pengobatan tradisional.

\section{HASIL DAN PEMBAHASAN}

Tabel 4.1. Distribusi Persepsi Pengetahuan dan Animo terhadap Pengobatan Tradisional

\begin{tabular}{|c|c|c|c|c|c|c|}
\hline \multirow{3}{*}{ Variabel Tetap (4) } & \multirow{3}{*}{$\begin{array}{c}\mathbf{N} \\
\text { (Jumlah } \\
\text { Responden = } \\
137 \text { orang) }\end{array}$} & \multicolumn{5}{|c|}{ Variabel Tidak Tetap (5) } \\
\hline & & \multicolumn{5}{|c|}{ Persepsi (\%) } \\
\hline & & SS & $\mathbf{S}$ & $\mathbf{N}$ & KS & TS \\
\hline \multicolumn{7}{|c|}{ Usia: } \\
\hline Dari 40 tahun keatas & 45 & $11.6 \%$ & $61.3 \%$ & $16.9 \%$ & $8.0 \%$ & $2.2 \%$ \\
\hline $30 \mathrm{~s} / \mathrm{d} 40$ tahun & 40 & $10.5 \%$ & $56.0 \%$ & $24.5 \%$ & $8.5 \%$ & $0.5 \%$ \\
\hline Dibawah 30 tahun & 52 & $10.0 \%$ & $55.8 \%$ & $26.2 \%$ & $7.7 \%$ & $0.4 \%$ \\
\hline
\end{tabular}

\section{Keterangan:}

- Persepsi: SS (Sangat Setuju); S (Setuju); N (Netral); KS (Kurang Setuju); TS (Tidak Setuju) Scoring: Sangat lemah (0-20); Lemah (21-40); Cukup (41-60); Kuat (61-80); Sangat kuat (81-100), Sumber Ridwan 2019

Tabel 4.1 menunjukkan dari 137 responden menyatakan ketiga kelompok usia (dibawah 30 tahun; 30-40 tahun dan 40 tahun keatas) rata-rata setuju bahwa pengobatan tradisional tumbuh menjamur, merupakan warisan nenek moyang, memberi bukti menyembuhkan tetapi fasilitas praktik masih seadanya dengan persentase $57,7 \%$ (skala cukup). Jika dilihat dari persentase skala cukup tersebut, terdapat faktor yang mempengaruhi masyarakat dalam memilih pengobatannya sesuai teori Green (1980), diantaranya yaitu faktor predisposisi yang mencakup pengetahuan dan sikap masyarakat terhadap kesehatan, tradisi dan kepercayaan masyarakat serta faktor pemungkin yang 
mencakup ketersediaan sarana dan prasarana atau fasilitas kesehatan bagi masyarakat (Janna, Raodahtul. 2019).

Sementara untuk memperkuat data juga dilakukan persentase kumulatif dari persepsi setuju dan sangat setuju responden berdasarkan ketiga kelompok usia, responden memiliki pengetahuan dan animo yang kuat terhadap pengobatan tradisional dengan persentase gabungan adalah $68,4 \%$ (skala kuat). Dimana pada penelitian Janna, Raodahtul 2019 menyatakan bahwa salah satu sistem pengetahuan dari pengobatan tradisional adalah pemanfaatan tumbuhan untuk pemenuhan kehidupan sehari-hari, antara lain sebagai bahan obat tradisional.

Pengetahuan dan animo responden terhadap pengobatan tradisional pada kelompok usia 40 tahun ke atas dinilai dengan skala kuat (persentase 61,3\%) dibandingkan dengan kelompok usia 30-40 tahun (skala cukup: 56,0\%) maupun kelompok usia dibawah 30 tahun (skala cukup: 55,8\%). Hal ini sejalan dengan pernyataan pada penelitian Sudibyo S,2007 yang menyatakan bahwa kelompok usia lansia memilih menggunakan pengobatan tradisional karena dianggap pengobatan tradisional lebih mudah dan praktis. Selain itu pengobatan tradisional juga dipilih karena memiliki efek samping lebih sedikit (Jabbar, dkk.2016). Berdasarkan perilaku tersebut dapat diketahui bahwa menggunakan obat tradisional secara turun temurun termasuk dalam upaya melestarikan kebudayaan. Hal ini diperkuat dengan pernyataan bahwa penggunaan obat tradisional erat kaitannya dengan pengetahuan, karena kurangnya tingkat pengetahuan seorang ibu, maka tingkat penggunaan obat tradisional menjadi semakin tinggi juga, hal ini dikarenakan pengetahuan ibu tentang obat modern yang sangat rendah sehingga ibu lebih memilih menggunakan obat tradisional yang memang telah digunakan secara turun termurun di keluarga (Jabbar et al., 2016). Selain itu juga diperkuat dari data yang diperoleh pada gabungan persepsi sangat setuju (SS) dan setuju (S) pada responden di Kabupaten Purwakarta bahwa persentase kelompok usia 40 tahun dinilai lebih kuat 72,9\% dibandingkan dari kelompok usia 30-40 tahun (cukup: 66,5\%) maupun dari kelompok usia 30 tahun (cukup: 65,8\%). Jennifer, H dan Saptutyningsih, 2015 juga menyatakan bahwa kemungkinan individu usia lanjut memilih pengobatan tradisional lebih tinggi dibandingkan dengan individu berusia muda, yang berarti semakin bertambah usia maka probabilitas untuk memilih pengobatan tradisional semakin tinggi. Sehingga jika 
dihubungkan faktor predisposisi pada penelitian yaitu usia berkorelasi dengan persepsi pengetahuan dan animo masyarakat terhadap pengobatan tradisional.

Tabel 4.2. Distribusi Persepsi Potensi Pengembangan terhadap Pengobatan Tradisional

\begin{tabular}{|c|c|c|c|c|c|c|}
\hline \multirow{3}{*}{ Variabel Tetap (4) } & \multirow{3}{*}{$\begin{array}{c}\mathbf{N} \\
\text { (Jumlah } \\
\text { Responden = } \\
\text { 137 orang) }\end{array}$} & \multicolumn{5}{|c|}{ Variabel Tidak Tetap (5) } \\
\hline & & \multicolumn{5}{|c|}{ Persepsi $(\%)$} \\
\hline & & SS & $\mathbf{S}$ & $\mathbf{N}$ & KS & TS \\
\hline \multicolumn{7}{|c|}{ Usia: } \\
\hline Dari 40 tahun keatas & 45 & $14.1 \%$ & $61.5 \%$ & $14.8 \%$ & $8.9 \%$ & $0.7 \%$ \\
\hline $30 \mathrm{~s} / \mathrm{d} 40$ tahun & 40 & $14.2 \%$ & $60.0 \%$ & $16.7 \%$ & $9.2 \%$ & $0.0 \%$ \\
\hline Dibawah 30 tahun & 52 & $16.0 \%$ & $58.3 \%$ & $18.6 \%$ & $6.4 \%$ & $0.6 \%$ \\
\hline
\end{tabular}

\section{Keterangan:}

- Persepsi: SS (Sangat Setuju); S (Setuju); N (Netral); KS (Kurang Setuju); TS (Tidak Setuju)

Scoring: Sangat lemah (0-20); Lemah (21-40); Cukup (41-60); Kuat (61-80); Sangat kuat (81-100), Sumber Ridwan 2019

Tabel 4.2 menunjukkan dari 137 responden yang diberikan kuisioner menyatakan setuju (skala cukup : 59,9\%) atas pernyataan bahwa pengobatan tradisional makin tumbuh menjamur, merupakan warisan nenek moyang dan biaya pelayanan pengobatan tradisional murah dilihat dari persepsi potensi pengembangan pengobatan tradisional yang diperkuat dalam pernyataan faktor pendorong masyarakat untuk mendayagunakan obat bahan alam antara lain karena mahalnya harga obat modern/sintesis yang mahal dan banyaknya efek samping (Pramono, S. 2002 Dewoto, HR. 2007), sehingga pengembangan pengobatan tradisional meningkat. Namun hal ini tidak sejalan dengan pernyataan bahwa profesi kesehatan/dokter masih enggan untuk meresepkan atau menggunakan cara pengobatan tradisional karena bukti ilmiah mengenai khasiat dan keamanan obat tradisional pada manusia masih kurang (Pramono, E.2002 dalam Dewoto, HR. 2007).

Jika digabungkan persepsi setuju dan sangat setuju maka menurut responden dari semua tingkatan usia, pengobatan tradisional memiliki potensi yang kuat untuk dikembangkan sebagi upaya kesehatan (skala kuat:74,7\%). Potensi pengembangan pengobatan tradisonal di Indonesia dinilai cukup tinggi karena pasar obat tradisional di Indonesia terus mengalami peningkatan, pada tahun 2001 sebesar Rp.1,3 triliun dan 2002 naik menjadi 1,5 triliun (Sampurno, 2003 dalam Hendri Wasito-Meningkatkan Peran Perguruan Tinggi melalui Pengembangan Obat Tradisional 2008). Hal tersebut karena 
keanekaragaman hayati tanaman obat di Indonesia merupakan sumber daya yang cukup potensial untuk dimanfaatkan dan dikembangkan sebagai bahan baku obat tradisional (Hendri Warsito 2008). Potensi pengembangan obat tradisional dapat digunakan untuk pengobatan dan menjaga kesehatan atau melalui penelitian terhadap bahan-bahan alam yang baru yang diprediksikan memiliki khasiat sebagai obat. (Hendr Warsito, 2008). Dalam hal ini upaya pengobatan tradisional sejalan dengan program penyelenggaraan pelayanan kesehatan dengan pendekatan promotif, preventif, kuratif dan rehabilitatif yang diselenggarakan secara terpadu, menyeluruh dan berkesinambungan.

Berdasarkan kelompok usia, potensi pengembangan pengobatan tradisional pada responden kelompok 40 tahun ke atas dengan persentase 75,6\% (skala kuat) adalah lebih besar dibandingkan kelompok usia lainnya. Hal ini sejalan dengan pernyataan yang menyatakan bahwa semakin bertambahnya usia maka probabilitas untuk memilih pengobatan tradisional semakin tinggi. Studi lain (Kristina et al., 2007) juga mengungkapkan bahwa usia memiliki pengaruh yang signifikan terhadap perilaku pengobatan sendiri yang rasional. Serta sejalan dengan pendapat Supardi, dkk 2003 menyatakan bahwa penduduk berusia lanjut ( $>56$ tahun) menggunakan obat tradisional lebih banyak 1,56 kali daripada penduduk yang bukan lanjut usia. (Jennifer, H dan Saptutyningsih, 2015).

Dapat disimpulkan bahwa potensi pengembangan pengobatan tradisional cenderung lebih besar diperoleh dari kelompok usia 40 tahun keatas dengan persentase 75,6\% dibanding kelompok usia 30-40 tahun (74,2\%) dan kelompok usia 30 tahun sebanyak 74,3\% yang diperoleh dari persepsi gabungan sangat setuju dan setuju. Perilaku kesehatan tersebut digolongkan kedalam faktor penguat (reinforcing factors) yang menguatkan seseorang untuk berperilaku sehat seperti dorongan dari orang tua, tokoh masyarakat atau teman sebaya yang menjadi panutan (Notoatmodjo, Soekidjo, 2011).

Tabel 4.3. Distribusi Persepsi Kepercayaan terhadap Khasiat Pengobatan Tradisional 


\begin{tabular}{|c|c|c|c|c|c|c|}
\hline \multirow{3}{*}{ Variabel Tetap (4) } & \multirow{3}{*}{$\begin{array}{c}\mathbf{N} \\
\text { (Jumlah } \\
\text { Responden }= \\
137 \text { orang) }\end{array}$} & \multicolumn{5}{|c|}{ Variabel Tidak Tetap (5) } \\
\hline & & \multicolumn{5}{|c|}{ Persepsi (\%) } \\
\hline & & SS & $\mathbf{S}$ & $\mathbf{N}$ & KS & TS \\
\hline \multicolumn{7}{|c|}{ Usia: } \\
\hline Dari 40 tahun keatas & 45 & $11.1 \%$ & $51.1 \%$ & $24.4 \%$ & $6.7 \%$ & $6.7 \%$ \\
\hline $30 \mathrm{~s} / \mathrm{d} 40$ tahun & 40 & $5.0 \%$ & $50.0 \%$ & $40.0 \%$ & $5.0 \%$ & $0.0 \%$ \\
\hline Dibawah 30 tahun & 52 & $0.0 \%$ & $53.8 \%$ & $38.5 \%$ & $7.7 \%$ & $0.0 \%$ \\
\hline
\end{tabular}

\section{Keterangan:}

- Persepsi: SS (Sangat Setuju); S (Setuju); N (Netral); KS (Kurang Setuju); TS (Tidak Setuju) Scoring: Sangat lemah (0-20); Lemah (21-40); Cukup (41-60); Kuat (61-80); Sangat kuat

(81-100), Sumber Ridwan 2019

Tabel 4.3 menunjukkan dari 137 responden yang memberikan persepsi setuju bahwa pengobatan tradisional cukup memberi bukti menyembuhkan penyakit adalah sebesar $51,7 \%$ (skala cukup) dimana responden percaya bahwa pengobatan tradisional sebagai bagian dari upaya kesehatan. Hal ini sejalan dengan program pemerintah dalam menaikkan derajat kesehatan yang optimal bahwa selain menggunakan kesehatan formal/modern juga menggunakan pengobatan tradisional (Undang-Undang No.36 Tahun 2009). Ketentuan mengenai pengobatan tradisional juga ditetapkan dalam Kemenkes No.1076 tahun 2003 tentang penyelenggaraan pengobatan tradisional (Dian Kartika, 2016). Pada praktiknya, banyak masyarakat yang termotivasi dan memiliki kepercayaan untuk berobat pada pelayanan kesehatan tradisional karena dianggap dapat mengobati penyakit kronis serta ketidakpercayaan masyarakat terhadap pengobatan modern karena dianggap gagal dalam mengobati penyakit.

Jika digabungkan persepsi setuju dan sangat setuju, persentase yang percaya bahwa pengobatan tradisional berkhasiat adalah sebesar 57,0\% untuk semua kelompok usia. Persentase tersebut dinyatakan cukup karena tumbuhan alam berkhasiat obat telah lama dikenal bahkan sejak ratusan tahun yang lalu, hanya sebagian kecil masyarakat yang mengetahui jenis-jenis tumbuhan obat (Nurrani, Lis, 2013).

Dimana tingkat kepercayaan penyembuhan pada pengobatan tradisional menurut persepsi responden yang setuju usia dibawah 30 tahun (cukup: 53,8\%) adalah lebih tiggi jika dibandingkan terhadap kelompok usia diatas 40 tahun (cukup 51,1\%) maupun kelompok usia 30-40 tahun (cukup 50\%). Meskipun demikian, nyatanya jika persepsi 
setuju dan sangat setuju digabungkan, responden kelompok usia diatas 40 tahun yang menyatakan tingkat kepercayaan penyembuhan pada pengobatan tradisional adalah sebesar 62,2\% lebih tinggi dari kelompok usia 30-40 tahun sebesar 55\% dan usia dibawah 30 tahun adalah 53,8\%. Hal tersebut membuktikan bahwa kelompok usia diatas 40 tahun lebih percaya khasiat pada pengobatan tradisional karena kesadaran akan bahan kimia yang didapatkan dari pengobatan medis dapat membawa dampak buruk bagi kesehatan (Jennifer, H dan Saptutyningsih. 2015). Sehingga faktor tersebut dianggap termasuk kedalam faktor pendorong masyarakat dalam memlih pengobatannya.

Tabel 4.4. Distribusi Persepsi Kepercayaan terhadap Mutu (Standarisasi) Pengobatan Tradisional

\begin{tabular}{|c|c|c|c|c|c|c|}
\hline \multirow{3}{*}{ Variabel Tetap (4) } & \multirow{3}{*}{$\begin{array}{c}\mathbf{N} \\
\text { (Jumlah } \\
\text { Responden = } \\
137 \text { orang) }\end{array}$} & \multicolumn{5}{|c|}{ Variabel Tidak Tetap (5) } \\
\hline & & \multicolumn{5}{|c|}{ Persepsi (\%) } \\
\hline & & SS & $\mathbf{S}$ & $\mathbf{N}$ & KS & TS \\
\hline \multicolumn{7}{|c|}{ Usia: } \\
\hline Dari 40 tahun keatas & 45 & $4.4 \%$ & $71.1 \%$ & $15.6 \%$ & $6.7 \%$ & $2.2 \%$ \\
\hline $30 \mathrm{~s} / \mathrm{d} 40$ tahun & 40 & $5.0 \%$ & $50.0 \%$ & $32.5 \%$ & $10.0 \%$ & $2.5 \%$ \\
\hline Dibawah 30 tahun & 52 & $1.9 \%$ & $50.0 \%$ & $36.5 \%$ & $11.5 \%$ & $0.0 \%$ \\
\hline
\end{tabular}

\section{Keterangan:}

- Persepsi: SS (Sangat Setuju); S (Setuju); N (Netral); KS (Kurang Setuju); TS (Tidak Setuju) Scoring: Sangat lemah (0-20); Lemah (21-40); Cukup (41-60); Kuat (61-80); Sangat kuat (81-100), Sumber Ridwan 2019

Tabel 4.4 menunjukkan bahwa responden semua kelompok usia setuju bahwa fasilitas praktik dari upaya pengobatan tradisional masih seadanya $(57,0 \%)$ bermakna bahwa fasilitas dari upaya pengobatan tradisional belum terstandarisasi adalah memiliki nilai cukup. Meskipun obat herbal di Indonesia dikenal sejak lama, tetapi sebagian besar belum memiliki latar belakang yang ilmiah karena dalam dunia kedokteran modern harus mengacu pada Evidanced Based Medicine (Satria, Darma, 2013).

Jika digabungkan persepsi setuju dan sangat setuju, maka responden percaya bahwa fasilitas praktik dari upaya pengobatan tradisional masih belum terstandarisasi adalah memiliki nilai kuat $(60,8 \%)$ dengan alokasi persentase yang dibedakan dalam kelompok usia diatas 40 tahun yaitu 75,5\% (skala kuat), kelompok usia 30-40 tahun sebesar 55\% (skala cukup) dan kelompok usia dibawah 30 tahun yaitu 51,9\%. 
Pada kelompok responden usia dari 40 tahun keatas memiliki tingkat kepercayaan yang lebih tinggi (kuat: 71,1\%) bahwa pengobatan tradisional belum terstandarisasi jika dibandingkan terhadap kelompok usia 30-40 tahun (50,0\%) maupun kelompok dibawah 30 tahun $(50,0 \%)$.

Persepsi kepercayaan responden terhadap belum terstandarisasinya pengobatan tradisional masih perlu dibuktikan scara ilmiah. Dalam hal ini, obat herbal yang umum ditemui di Indonesia masih berputar pada kategori Jamu dan OHT. Penggunaan dan khasiatnya bukan berdasarkan uji klinis, melainkan testimoni orang yang sembuh menggunakan obat herbal. Agar setara dengan obat modern, obat tradisional harus melewati tingkatan uji klinis. Sehingga jika telah lulus uji klinis maka dapat disebut sebagai fitofarmaka yang banyak diresepkan oleh dokter dan dapat beredar di pusat pelayanan kesehatan (Satria, 2013). Dapat dihubungkan bahwa semakin tinggi tingkat kepercayaan responden terhadap belum terstandarnya mutu pengobatan tradisional disebabkan karena hal ini sebenarnya hanya justifikasi dari testimoni beberapa orang saja dan belum ada standar penelitiannya, sehingga mendorong Menteri Kesehatan membuat Permenkes No.003/2010 tentang saintifikasi jamu terkait pembuktian ilmiah obat tradisional melalui penelitian berbasis pelayanan dan pemanfaatan obat tradisional dalam upaya kesehatan. Dalam hal ini, pernyataan tersebut diperkuat sebagai faktor pemungkin (enabling factors) yaitu faktor-faktor yang memungkinkan atau yang menfasilitasi perilaku seseorang terhadap pengobatan tradisional (Notoatmodjo, 2011).

\section{KESIMPULAN}

Diperoleh bahwa perilaku masyarakat Kabupaten Purwakarta terhadap pengobatan tradisional masih cukup tinggi. Perkembangan pengobatan tradisional diapresiasi oleh masyarakat dari semua kelompok usia. Dimana kelompok usia diatas 40 tahun, menyatakan persetujuan paling tinggi bahwa pengobatan tradisional potensial untuk dikembangkan, memiliki khasiat untuk penyembuhan namun fasilitas pengobatan belum terstandar dibandingkan kelompok usia 30-40 tahun maupun dibawah 30 tahun. 


\section{DAFTAR PUSTAKA}

Departemen Kesehatan RI. Undang-Undang Republik Indonesia Nomor 36 Tahun 2009 Tentang Kesehatan. Jakarta: Kementerian Kesehatan Republik Indonesia.

Dewoto, H.R. 2007. Pengembangan Obat Tradisional Indonesia Menjadi Fitofarmaka. Majalah Kedokteran Indonesia. 57(7), 201-205.

Kartika, D. 2016. Pelayanan Kesehatan Tradisional dan Perlindungan Hukum bagi Pasien. SOEPRA Jurnal Hukum Kesehatan, 2(1), 1-16.

Jabbar, Asriullah., Musdalipah., Nurwati, Andi. 2016. Studi Pengetahuan, Sikap dan Tindakan terhadap Penggunaan Obat Tradisional bagi Masyarakat di Desa SabiSabila Kecamatan Moweme Kabupaten Kolaka Timur. Majalah Farmasi Sains, dan Kesehatan. Pharmauho, 3(1),19-22.

Raodahtul, J. 2019. Pengetahuan Lokal tentang Pemanfaatan Tanaman Obat pada Masyarakat Tolaki di Kabupaten Konawe Sulawesi Tenggara. Pangadereng. 5(1), 46-63.

Jennifer, H dan Saptutyningsih. 2015. Preferensi Individu Terhadap Pengobatan Tradisional di Indonesia. Jurnal Ekonomi dan Studi Pembangunan. 16(1), 26-41.

Fariza, I. 2013. Gambaran Penggunaan Obat Tradisional untuk Pengobatan Seindiri pada Masyarakat di Desa Jimus Polanharjo Klaten. Universitas Muhammadiyah Surakarta. http://eprints.ums.ac.id/26073/

Notoatmodjo, S. 2011. Ilmu Kesehatan Masyarakat: Ilmu \& Seni. Jakarta: Rineka Cipta.

Nurrani, L. 2013. Pemanfaaran Tradisional Tumbuhan alam Berkhasiat Obat oleh Masyarakat di Sekitar Cagar Alam Tangale. Jurnal Info BPK Manado. 3(1).

Satria, D. 2013. Complementary and Alternative Medicine (CAM). Idea Nursing Journal, 1(3), 82-90.

Sugiyono, 2017. Metode Penelitian Kuantitatif, Kualitatif, dan R\&D. Bandung Alfabeta.

Supardi, Sudibyo dan Susyanti L, Andi. 2007. Penggunaan Obat Tradisional dalam Upaya Pengobatan Sendiri di Indonesia. Diakses tanggal 20 Oktober 2019. http://ejournal.litbang.depkes.go.id/index.php/BPK/article/view/10.

Utami, E.R. 2018. Hubungan Pengetahuan Keluarga dengan Penggunaan Obat Tradisional di Desa Nunggalrejo Kecamatan Punggur Kabupaten Lampung Tengah. Diperoleh tanggal 27 November 2019, dari http://digilib.unila.ac.id

Wasito, H. 2008. Meningkatkan Peran Pergutuan tinggi melalui Pengembangan Obat Tradisional. MIMBAR, 24(2), 117-127. 